Original Article (short paper)

\title{
Validation and reliability of a sources of knowledge scale for Brazilian coaches
}

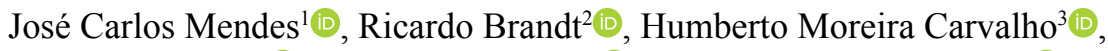 \\ Sebastián $\mathrm{Feu}^{4}{ }^{\oplus}$, Sergio Jose Ibañez ${ }^{5}$, Juarez Vieira Nascimento ${ }^{6}$ \\ ${ }^{1}$ Universidade Estadual do Oeste do Paraná, Marechal Candido Rondon, PR, Brasil, ${ }^{2}$ Universidade Estadual do Oeste \\ do Paraná, Cascavel, PR, Brasil; ${ }^{3}$ Universidade Federal de Santa Catarina, Florianópolis, SC, Brasil; ${ }^{4}$ Universidad de \\ Extremadura Facultad de Ciencias, Badajoz, Extremadura, Spain, ${ }^{5}$ Universidad de Extremadura Facultad de Ciencias, Caceres, \\ Extremadura, Spain; ${ }^{6}$ Universidade Federal de Santa Catarina, Departamento de Educação Física, Florianópolis, SC, Brasil
}

\begin{abstract}
Aim: The present study examined the validity of the Coaches' Training Profile Questionnaire (QPFT) in Brazilian coaches. Method: The questionnaire was back-translated and content validation was performed by an expert panel. Construct validation was based on the application of the questionnaire to 212 coaches from the state of Paraná, considering the Cronbach's alpha to examine internal consistency, Pearson's correlation and intraclass correlation coefficient (ICC) for test-retest reliability, and exploratory and confirmatory factor analysis. Results: The questionnaire showed high internal consistency, with Cronbach's alpha coefficient higher than .80. Correlations of the dimensions and ICC of the items indicated high reliability for the three dimensions of the questionnaire. The results of exploratory factor analysis explained a variance of $69.75 \%$, with the AE factor explaining the largest portion of variance $(27.01 \%)$ and the AT factor explaining the lowest portion of variance (21.14\%). The absolute, parsimonious and incremental fit indices [X2 and p-value; X2/df; CFI, PCFI, GFI, PGFI, TLI, RMSEA (with 90\% CI), and MECVI] were high. Conclusion: The Brazilian version of the QPFT presents a reliable and valid factor structure to identify coaches' knowledge sources in Brazil.
\end{abstract}

Keywords: knowledge, coach, questionnaire and validation.

\section{Introduction}

The development of coaches has been of interest as coaching is an integrated, complex and differentiated nature of this process ${ }^{1}$. Coach development must be continuous through the acquisition of knowledge sources in situations of mediated, unmediated and internal learning ${ }^{2}$ within the formal and informal context ${ }^{3}$.

In Brazil, coaches' development is regulated by the 1998 regulation of the Physical Education profession, which is limited to the formal context within ungraduated courses, recently updated by Resolution CNE / CES 6/2018. The Physical Education undergraduate programs are predominantly based on general knowledge sources and with insufficient workloads of sports knowledge and specific sports coaches activity ${ }^{4}$. In addition, Physical Education courses in Brazil do not appear to use facilitation strategies during coaches training, such as informal sources of knowledge ${ }^{5-7}$.

It is widely recognized the need for the development of increasingly capacitated and qualified coaches ${ }^{8}$. Hence, there is a need to expand and facilitate the access of coaches to the most significant sources of knowledge in different learning contexts (formal and informal), likely promoting continuous learning and development in professional practice $e^{7,9-13}$.

There has been a substantial increase in the available data considering the training and development of coaches ${ }^{14}$ showing that coaches' learning and development through experiencing a wide and varied range of informal and self-directed learning situations $^{12,15,16}$, such as peer interaction and real-world practice, real-world practice of participation in mentoring schemes ${ }^{17-19}$. Also, various versions of community coaching learning have been reported ${ }^{20-22}$, which are common to social learning approaches ${ }^{6}$. Research in the coaching Brazilian context, although scarce $^{23}$, has been consistent with results in the literature, in particular considering the prevalence of informal sources to obtain knowledge needed daily practice ${ }^{24}$. However, the main emphasis remains on sport-specific technical knowledge, and formal sources based on undergraduate Physical Education curriculums ${ }^{25}$.

Considering coach development through different knowledge pathways requires the identification of the most significant sources of coaching with respect to the professional practice for the structuring of the training process. The preferences for certain sources of knowledge are directly related to the personal convictions and personal experiences of the coach and likely vary according to a competitive level, time of experience, and educational background of the coaches ${ }^{7,13,26}$. Given that there is no available Portuguese language measure to identify coaches' sources of knowledge, the present study examined the validity of sources of knowledge scale that can be used by Brazilian coaches. Specifically, it was examined the content validity, reliability and construct validity of the Portuguese version of the Coaches' Training Profile Questionnaire. 


\section{Methods}

\section{Participants}

A total of 212 coaches ( 23 female coaches; 189 male coaches) aged 39.4 years $(\mathrm{SD}=9.7$ years). The participants were coaching the following sports: basketball $(\mathrm{n}=18)$, futsal $(n=35)$, soccer $(n=19)$, handball $(n=86)$, volleyball $(n=38)$, and other sports $(\mathrm{n}=16)$. Regarding educational background, 120 coaches had a degree in Physical Education, 75 had a postgraduate degree in different areas, and 17 coaches had no specific higher education. Ninety-eight of the coaches had experience with athletes competing at national level competitions, 82 had experience with athletes competing at state level competitions, and 25 had experience with athletes competing at regional/municipal level competitions. Only seven coaches had experience with athletes who compete at international level. On average, the coaches in the present study had $13.9(\mathrm{SD}=9.7)$ years of experience.

\section{Instruments}

The Coaches' Training Profile Questionnaire (QPFT) in the Spanish acronym was originally proposed by Feu , Ibáñez ${ }^{26}$ in Spanish, based on studies by Ibáñez ${ }^{27}$ and Ibáñez ${ }^{28}$. The instrument is aimed to establish the sources of knowledge used by coaches in three dimensions: academic training (AT), athlete experience (AE), and professional experience (PE). Each dimension consists of five items that comprise learning, experience, knowledge, methods, and exercises used by the coaches. The instrument is composed of 15 items, based on a Likert-type scale ranging from 1 to $10(1=$ fully disagree to $10=$ fully agree), as shown in Figure 1.

\begin{tabular}{|ccc|}
\hline Dimension & Indicator & Item \\
\hline & Methodologies & 7. Methods that were used by my coaches. \\
Athlete & Learning & 11. What I learned from other coaches while I was an athlete. \\
Experience (AE) & Experience & 1. The experiences I have gained throughout my career as an athlete. \\
& Knowledge & 4. The knowledge gained from the coaches who trained me. \\
& Exercise & 13. The exercises and tasks I learned when I was an athlete. \\
\hline & Methodologies & 5.The methodological criteria learned in training courses for coaches. \\
Academic & Learning & 14. What I learned during my training as a coach. \\
Training (AT) & Experience & 6. What I learned during my Physical Education course. \\
& Knowledge & 8. The knowledge learned in the training courses I attended. \\
& Exercises & 9. The exercises and tasks learned during training courses for coaches. \\
Methodologies & 2. The methodology I created from my own experience during the training process \\
Professional & Learning & 15. What I learned on my own initiative without the help of courses or other people. \\
& Experience & 10. Putting into practice the theories elaborated based on my personal experience as a coach. \\
& Knowledge & 12. The knowledge acquired throughout my work and my experience as a coach. \\
& Exercises & 3. The experience gained from the exercises I created during the training process.
\end{tabular}

Figure 1. Analytical matrix containing the dimensions, indicators, and QPFT items.

\section{Procedures}

The validation of the QPFT to the Portuguese language (Brazil) was performed using the general guidelines recommended by Beaton, Bombardier, Guillemin, Ferraz ${ }^{29}$ and Hambleton, Merenda $^{30}$, which consist of a back-translation ${ }^{31}$, subsequent revision and correction of the technical terms used in the translation, and adaptation of the items for understanding by the target audience ${ }^{32}$. In addition, the translated version of the instrument was submitted to 10 experts for the evaluation of content validity based on language clarity and practical and theoretical relevance. Test-retest application was used to verify the instrument's stability and internal consistency.

The study was approved by the Research Ethics Committee of the State University of Western Paraná ( $\mathrm{n}^{\circ}:$ 1835025). The coaches were invited to participate in this study during the competitions held in Paraná state in the first semester of the 2017 season. The questionnaires were sent via email with two fill-in options (Office 2003 Word document or Google Docs form).

\section{Data Analysis}

Inspection of distribution was performed using visual inspections and Kolmogorov-Smirnov test. Heteroscedasticity was present, with trends of asymmetries and negative kurtosis observed. The content validity coefficient was calculated using the procedures recommended ${ }^{33,34}$. Internal consistency was evaluated using Cronbach's alpha reliability coefficient. Pearson correlation coefficient and the intraclass correlation coefficient (ICC) were calculated for analysis of the reliability of the dimensions and items in the test-retest ${ }^{33-35}$.

For construct validation it was used an exploratory factor analysis, with a Kaiser-Meyer-Olkin index of sampling adequacy of 0.70 , Bartlett's sphericity test and Varimax rotation ${ }^{36}$ using the following criteria: items with eigenvalues $>1$, factors that explained $>5 \%$ of the variance, and saturation $\geq 0.45$ by virtue of the sample in question ${ }^{37}$. In addition, confirmatory factor analysis was performed to verify the validity of the instrument using absolute, parsimonious and incremental fit indices ${ }^{36}$. Analyses were performed using SPSS and Amos 23.0. 


\section{Results}

After translation, analysis by an expert panel and application of the instrument to the coaches, the final content validity coefficient of each item ranged from 0.82 to 1.00 for language clarity, practical relevance, and theoretical relevance. The total content validity coefficient was 0.90 , with a coefficient of 0.96 for language clarity,
0.97 for practical relevance and 0.90 for theoretical relevance $^{38}$.

Reliability estimated separately for each dimension is summarized in Table 1. Cronbach's alpha coefficients were observed to be higher than those recommended in the literature for both individual and clustered dimensions ${ }^{37}$. In addition, correlations of the dimensions in the test-retest and the ICC of the items were high for the three dimensions of the instrument ${ }^{37}$.

Table 1. Internal consistency of the dimensions of the Brazilian version of the QPFT and reliability of dimensions and items in the test-retest.

\begin{tabular}{lcccc}
\hline \multicolumn{1}{c}{ Dimension of the QPFT } & Cronbach alpha & Pearson correlation & Items & ICC (95\%) items \\
\hline Athlete Experience (AE) & $0,85^{*}$ & $0,96^{*}$ & $1,4,7,11,13$ & $(0,85 / 0,90 / 0,79 / 0,88 / 0,91)^{*}$ \\
Academic Training (AC) & $0,88^{*}$ & $0,91^{*}$ & $5,6,8,9,14$ & $(0,89 / 0,93 / 0,88 / 0,87 / 0,84)^{*}$ \\
Professional Experience (PE) & $0,85^{*}$ & $0,88^{*}$ & $2,3,10,12,15$ & $(0,68 / 0,61 / 0,91 / 0,87 / 0,91)^{*}$ \\
Total & $0,89^{*}$ & & & $0,87^{*}$ \\
\hline
\end{tabular}

* Significant at $\mathrm{p} \leq .001$.

Factor analysis estimates for the QPFT are summarized in Table 2. The estimated Kaiser-Meyer-Olkin coefficient $(\mathrm{X} 2=0,0859-\mathrm{p}$ $\leq .0001)$, as well as Bartlett's sphericity test $(\mathrm{X} 2=1886,79-\mathrm{p}$ $\leq, 0001)$, indicated the absence of identity problems. The correlations between items were moderate or high, allowing the identification of three dimensions with five items each. The eigenvalues were greater than one and the content saturation of the item was higher than 0,45 in the respective dimensions (Table 2).

Table 2. Factor analysis of the QPFT with Varimax rotation (English and Portuguese version).

\begin{tabular}{|c|c|c|c|}
\hline \multirow[b]{2}{*}{$\begin{array}{l}\text { To perform my duties as a coach I prefer ... } \\
\text { Para desempenhar minhas funções como treinador prefiro ... }\end{array}$} & \multicolumn{3}{|c|}{ Dimension } \\
\hline & $\begin{array}{c}\text { Athletic } \\
\text { Experience } \\
\text { (AE) }\end{array}$ & $\begin{array}{l}\text { Academic } \\
\text { Training } \\
\text { (AT) }\end{array}$ & $\begin{array}{c}\text { Professional } \\
\text { Experience } \\
\text { (PE) }\end{array}$ \\
\hline 7. Methods that were used by my coaches. Métodos que eram utilizados pelos meus treinadores. & 0,893 & & \\
\hline $\begin{array}{l}\text { 11. What I learned from other coaches while I was an athlete. O que aprendi com outros treinadores } \\
\text { enquanto era atleta. }\end{array}$ & 0,856 & & \\
\hline $\begin{array}{l}\text { 1. The experiences I have gained throughout my career as an athlete. As experiências que adquiri ao } \\
\text { longo da minha carreira como atleta. }\end{array}$ & 0,829 & & \\
\hline $\begin{array}{l}\text { 4. The knowledge gained from the coaches who trained me. } \\
\text { Os conhecimentos adquiridos com os treinadores que me treinaram. }\end{array}$ & 0,800 & & \\
\hline $\begin{array}{l}\text { 13. The exercises and tasks I learned when I was an athlete. Os exercícios e tarefas que aprendi quando } \\
\text { era jogador. }\end{array}$ & 0,759 & & \\
\hline $\begin{array}{l}\text { 5. The methodological criteria learned in training courses for coaches. Os critérios metodológicos } \\
\text { aprendidos em cursos de formação de treinadores. }\end{array}$ & & 0,880 & \\
\hline $\begin{array}{l}\text { 14. What I learned during my training as a coach. O que aprendi durante a minha formação como } \\
\text { treinador. }\end{array}$ & & 0,867 & \\
\hline $\begin{array}{l}\text { 6. What I learned during my Physical Education course. O que aprendi durante a minha formação } \\
\text { acadêmica na área de Educação Física. }\end{array}$ & & 0,760 & \\
\hline $\begin{array}{l}\text { 8. The knowledge learned in the training courses I attended. Os conhecimentos aprendidos nos cursos de } \\
\text { formação que participei. }\end{array}$ & & 0,658 & \\
\hline $\begin{array}{l}\text { 9. The exercises and tasks learned during training courses for coaches. Os exercícios e tarefas } \\
\text { aprendidos durante os cursos de formação de treinadores. }\end{array}$ & & 0,572 & \\
\hline $\begin{array}{l}\text { 2. The methodology I created from my own experience during the training process. A metodologia que } \\
\text { criei a partir da minha própria experiência à frente do processo de treino. }\end{array}$ & & & 0,806 \\
\hline $\begin{array}{l}\text { 15. What I learned on my own initiative without the help of courses or other people. O que aprendi por } \\
\text { iniciativa própria sem auxílio de cursos ou de outras pessoas. }\end{array}$ & & & 0,747 \\
\hline $\begin{array}{l}\text { 10. Putting into practice the theories elaborated based on my personal experience as a coach. Pôr em } \\
\text { prática as teorias elaboradas com base na minha experiência pessoal como treinador. }\end{array}$ & & & 0,745 \\
\hline $\begin{array}{l}\text { 12. The knowledge acquired throughout my work and my experience as a coach. Os conhecimentos } \\
\text { adquiridos ao longo do meu trabalho e da minha experiência como treinador. }\end{array}$ & & & 0,666 \\
\hline $\begin{array}{l}\text { 3. The experience gained from the exercises I created during the training process. A experiência } \\
\text { adquirida com os exercícios criados por mim no processo de treino. }\end{array}$ & & & 0,654 \\
\hline Eigenvalue & 6,28 & 1,53 & 2,59 \\
\hline$\%$ variance & $27,01 \%$ & $21,14 \%$ & $21,21 \%$ \\
\hline Cronbach Alpha & 0,93 & 0,83 & 0,82 \\
\hline
\end{tabular}


The model explained $69.8 \%$ of variance with the largest portion of variance being explained by the AE factor, followed by the PE and AT factors. The questionnaire showed acceptable internal consistency, with the highest alpha coefficient being obtained for the AE dimension. Although lower, the coefficients obtained for the PE and AT dimensions were considered optimal. Regarding the descriptive data, the mean values indicated that the AT dimension $(8.17 \pm 1.44)$ obtained the highest degree of agreement between coaches, followed by PE $(7.80 \pm 1.64)$ and $\mathrm{AE}(6.87 \pm 2.23)$ with the lowest agreement.

After exploratory factor analysis confirmed content saturation of the items for the three factors to be identical to the original QPFT scale. The assumptions of confirmatory factor analysis were verified by identifying the existence of outliers by means of multivariate measures and Mahalanobis distance, excluding three coaches (T4, T21, and T39), as well as normality in relation to the univariate distribution of the data (asymmetry and flatness) and multivariate distribution (Mardia coefficient of multivariate kurtosis). The confirmatory analysis was identical to the measurement model proposed by the authors of the original version of the instrument, which was tested using maximum likelihood estimation and the most recommended indices of absolute, parsimonious and incremental (Figure 2). The values obtained were considered superior to those recommended in the literature ${ }^{39}$.

The standardized solution is presented in Figure 2. Adjustments were necessary due to measurement errors of the variables that showed correlations between some items. Specification of the model was based on a univariate approach, with only one parameter being added to the model at a time since the values can change substantially from one test to another ${ }^{40}$. Thus, the covariance of some items was added during construction of the model proposed in Figure 2 (4 "The knowledge gained from the coaches who trained me" and 7 - "Methods that were used by my coaches"; 3 - "The experience gained from the exercises I created during the training process" and 15 - "What I learned on my own initiative without the help of courses or other people"; 10 - "Putting into practice the theories elaborated based on my personal experience as a coach" and 12 - "The knowledge acquired throughout my work and my experience as a coach"; 9 - "The knowledge acquired throughout my work and my experience as a coach" and 14 - "The knowledge acquired throughout with my work and my experience as a coach") of theoretical relevance because they are linked within the same factor and some covariances between errors of items of different factors ( 7 - "Methods that were used by my coaches" and 8 "The knowledge learned in the training courses I attended"; 5 - "The methodological criteria learned in training courses for coaches" and 10 - "Putting into practice the theories elaborated based on my personal experience as a coach"; 14 - "What I learned during my training as a coach" with 10 - "Putting into practice the theories elaborated based on my personal experience as a coach" and 12 - "The knowledge acquired throughout my work and my experience as a coach"), indicating the existence of problematic items, which show some non-orthogonality of the model.

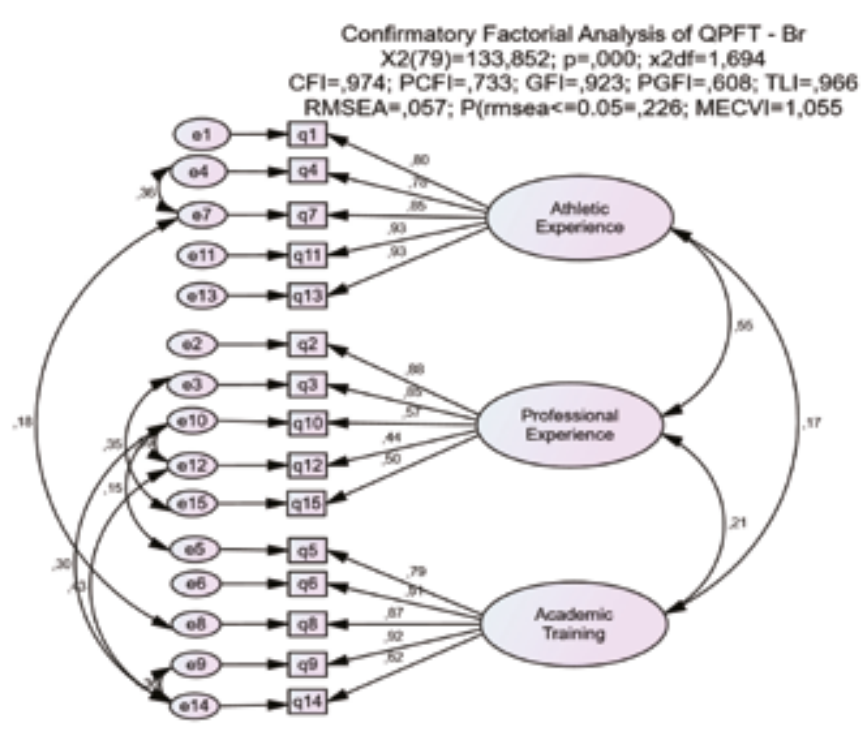

Figure 2. Factor load and intercorrelations between factors of each item in the three-factor model with 15 items of the Brazilian version of the Coaches' Training Profile Questionnaire (QPFT).

After adjustment (Figure 2), the absolute results were X2 of 133.85 ( $\mathrm{df}=79), \mathrm{X} 2 / \mathrm{df}$ of $1.69-\mathrm{p}<0.001$ and GFI of 0.92 , which are considered "satisfactory", while the relative results were 0.97 and 0.96 for CFI and TLI, respectively, considered "very satisfactory" 40,41 . Regarding the other fit indices, the parsimonious fit (PCFI $=0.73$ and PGFI 0.60), population discrepancy $(\mathrm{RMSEA}=0.05)$ and index based on information theory $(\mathrm{MECVI}=1.05)$ reached values accepted in the literature and considered "satisfactory"

\section{Discussion}

The present study examined the content validity, reliability and construct validity of the Portuguese version of the Coaches' Training Profile Questionnaire. Overall, the results showed that the translated version was of the QPFT is valid to examine the sources of knowledge of Brazilian coaches. The Cronbach alpha coefficients observed were high for the dimensions of the QPFT $(>0,80)^{42}$. The present results were consistent with the original study, differing only in the higher alpha Cronbach coefficients for the sources of knowledge. In the original study, the highest coefficient was obtained for the AE dimension. Noteworthy, the present results were higher than those found in similar translation and transcultural adaptation procedures ${ }^{43-45}$.

The present results showed a strong correlation between dimensions in the test-retest ${ }^{38}$, with highly reliable ${ }^{34}$. The results of the instrument validation process observed are similar to those observed in other studies ${ }^{44,46-49}$.

Often, the validation of questionnaires is reported based only on confirmatory factorial analysis ${ }^{44,46}$. This procedure is limited, as an exploratory, followed by a confirmatory factorial analysis is more adequate to explain the set of observed variables ${ }^{50}$. The validation by exploratory factor analysis involves the scientific verification of the legitimacy of the representation of the items in relation to the conceptual model of the original study. The 
present observations showed substantially high factor loads $(>0.70)$, contributing significantly to the evaluation of the construct $^{36,51}$.

The Brazilian version of the QPFT presents similarity in exploratory factor analyzes with the original study ${ }^{52}$ assuring the invariance of measurement ${ }^{33}$, similarly evaluating the same construct in different populations. The specific characteristics of the training process of the coaches were the determining factors in the observed residual covariance, representing a common and non-random systematic measurement error, which end up reflecting the bias of the integrated, complex and differentiated trainer process of the coaches ${ }^{1,40}$.

The confirmatory factorial results of the final model were consistent with the standard criteria recommended ${ }^{39,53}$, indicating that our model agrees with the original model. This adequacy was supported by the three factors that showed a satisfactory factorial validity when compared to the original model and other validated instruments of other scientific areas ${ }^{47,54-56}$. Although there is disagreement on the processes for adapting instruments to other contexts ${ }^{43,44}$, there is consensus that the procedures should maintain the characteristics of the instrument independent of the applied contexts, whether in the original form or an adapted form, and to meet the adjustments related to the population characteristics $^{57,58}$.

Despite the lack of participation of coaches in some sporting modalities and the concentration of the coaches investigated in one Brazilian state, it is believed that the invariance assumption of the Brazilian version of the QPFT allows its generalization to other regions of the country, irrespective of the sport modality studied. It should be emphasized that the Brazilian version of the QPFT will enable studies that explore the level of association of sources of coaching knowledge with different factors, such as coaches' academic training, athletic and professional experience, competitive level, environmental characteristics (clubs, teams, infrastructure), and socioeconomic indicators of coaches who work in different sport modalities and regions of Brazil.

\section{Conclusions}

The Brazilian version of the QPFT showed a factor structure with acceptable reliability. Furthermore, the factor structure was valid both in content and construct. Given the evidence of the stability of scores, internal consistency, and factorial structure, confirming 15 items aggregated in three dimensions, similar to the original scale, the Portuguese version of the QPFT is a valid questionnaire to examine the sources of knowledge prioritized by coaches in the development of their professional performance.

\section{References}

1. Gilbert WD, Trudel P. Analysis of coaching science research published from 1970-2001. Res Q Exerc Sport. 2004;75(4):388-99.
2. Moon JA. A handbook of reflective and experiential learning: Theory and practice: Psychology Press; 2004.

3. Trudel P, Culver D, Werthner P. Considerations for coach development administrators. Routledge handbook of sports coaching. 2013:375.

4. Milistetd M, Ciampolini V, Salles WN, Ramos V, Galatti LR, Nascimento JV. Coaches' development in Brazil: structure of sports organizational programmes. Sports Coach. Rev. 2016;5(2):138-52.

5. Brasil VZ, Ramos V, Barros TEdS, Godtsfriedt J, Nascimento JV. A trajetória de vida do treinador esportivo: As situações de aprendizagem em contexto informal. Movimento. 2015;21(3):815.

6. Stoszkowski J, Collins D. Sources, topics and use of knowledge by coaches. J Sports Sci. 2016;34(9):794-802.

7. González-Rivera MD, Campos-Izquierdo A, Villalba AI, Hall ND. Sources of knowledge used by Spanish coaches: A study according to competition level, gender and professional experience. Int $\mathbf{J}$ Sports Sci Coach. 2017;12(2):162-74.

8. ICCE. A strategy for the International Council for Coach Education for the period 2010-2015. Building the coaching community across the globe: International Council for Coaching Excellence (Icce). 2010.

9. Nash C, Collins D. Tacit Knowledge in Expert Coaching: Science or Art? Quest. 2006;58(4):465-77.

10. Carter A, Bloom G. Coaching knowledge and success: going beyond athletic experiences. J Sport Behav. 2009;32(4):419-37.

11. Schempp PG, Webster C, McCullick BA, Busch C, Sannen Mason I. How the best get better: an analysis of the self-monitoring strategies used by expert golf instructors. Sport Educ Soc. 2007;12(2):175-92.

12. Erickson K, Bruner MW, MacDonald DJ, Côté J. Gaining insight into actual and preferred sources of coaching knowledge. Int J Sports Sci Coach. 2008;3(4):527-38.

13. Cunha AFVP, Estriga MLD, Batista PMF. Fontes de conhecimento percebidas pelos treinadores: estudo com treinadores de andebol

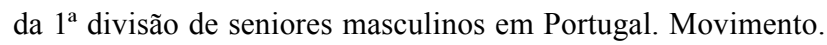
2014;20(3):917.

14. Cushion C, Nelson L, Armour K, Lyle J, Jones R, Sandford R, et al. Coach learning and development: A review of literature. London: The national Coaching Foundation; 2010.

15. Lemyre F, Trudel P, Durand-Bush N. How youth-sport coaches learn to coach. Sport Psychol. 2007;21(2):191-209.

16. Wright T, Trudel P, Culver D. Learning how to coach: the different learning situations reported by youth ice hockey coaches. Phys Educ Sport Pedagogy. 2007;12(2):127-44.

17. Cushion CJ, Armour KM, Jones RL. Locating the coaching process in practice: models 'for' and 'of' coaching. Phys Educ Sport Pedagogy. 2006;11(01):83-99.

18. Cushion C. Mentoring: Harnessing the power of experience. The sports coach as educator: Routledge; 2006. p. 146-62.

19. Nash C. Development of a mentoring system within coaching practice. JoHLSTE. 2003;2(2):39-47.

20. Culver D, Trudel P. Cultivating coaches' communities of practice: Developing the potential for learning through interactions. The sports coach as educator: Routledge; 2006. p. 115-30.

21. Gilbert W, Gallimore R, Trudel P. A learning community approach to coach development in youth sport. Journal of coaching education. 2009;2(2):3-23. 
22. Trudel P, Gilbert WD. Communities of practice as an approach to foster ice hockey coach development. Safety in ice hockey: Fourth volume: ASTM International; 2004.

23. Galatti L, Bettega OB, Brasil VZ, Souza Sobrinho AEP, Bertram R, Tozetto AVB, et al. Coaching in Brazil sport coaching as a profession in Brazil: an analysis of the coaching literature in Brazil from 2000-2015. International Sport Coaching Journal. 2016;3(3):316-31.

24. Ramos V, Graça A, Nascimento JVd, Silva Rd. A aprendizagem profissional-as representações de treinadores desportivos de jovens: quatro estudos de caso. Motriz: J. Phys. Ed. 2011;17(2):280-91.

25. Rodrigues HA, Costa GDCT, Santos Junior EL, Milistetd M. As fontes de conhecimento dos treinadores de jovens atletas de basquetebol. Motrivivência. 2017;29(51):100-18.

26. Feu S, Ibáñez S, Lorenzo A, Giménez S. El conocimiento profesional adquirido por el entrenador de balonmano: experiencias y formación. Rev Psicol Deporte. 2012;21(1):107-15.

27. Ibáñez S. Variables que afectan al establecimiento de los modelos de entrenador de baloncesto. Habilidad Motriz: Revista de ciencias de la actividad fisica y del deporte. 1997(10):30-7.

28. Ibáñez S. Los modelos del entrenador deportivo basados en el rol predominante. Revista Española de Educación Física y Deportes. 1997;4(4):35-42.

29. Beaton D, Bombardier C, Guillemin F, Ferraz MB. Recommendations for the cross-cultural adaptation of the DASH \& QuickDASH outcome measures. Institute for Work \& Health. 2007;1(1):1-45.

30. Hambleton RK, Merenda PF, Spielberger CD. Using Bilinguals to Evaluate the Comparability of Different Language Versions of a Test. Hambleton RK, Merenda PF, Spielberger CD, editors. New Jersey: Lawrence Erlbaum Associates, Inc., Publishers; 2005.

31. Gudmundsson E. Guidelines for translating and adapting psychological instruments. Nordic Psychology. 2009;61(2):29-45.

32. Weeks A, Swerissen H, Belfrage J. Issues, challenges, and solutions in translating study instruments. Evaluation Review. 2007;31(2):153-65.

33. Reise SP, Widaman KF, Pugh RH. Confirmatory factor analysis and item response theory: two approaches for exploring measurement invariance. Psychological bulletin. 1993;114(3):552.

34. Raykov T, Marcoulides GA. Introduction to psychometric theory: Routledge; 2011.

35. Cicchetti DV. Guidelines, criteria, and rules of thumb for evaluating normed and standardized assessment instruments in psychology. Psychol Assess. 1994;6(4):284.

36. Tabachnick BG, Fidell LS. Principal components and factor analysis. Using multivariate statistics. 42001. p. 582-633.

37. Hair J, Black W, Babin B, Anderson R, Tatham R. Multivariate data analysis (7 Th). Edinburgh Gate - Harlow: Pearson Prentice Hall; 2014.

38. Hernández-Nieto RA. Contributions to statistical analysis:The Coefficients of Proportional Variance, Content Validity and Kappa. Merida (Venezuela): BookSurge Publishing.; 2002.

39. Marôco J. Análise de equações estruturais: Fundamentos teóricos, software \& aplicações: ReportNumber, Lda; 2010.
40. Byrne BM. Structural Equation Modeling With AMOS: Basic Concepts, Applications, and Programming: Routledge; 2016.

41. Kline P. An easy guide to factor analysis: Routledge; 2014.

42. Blunch N. Introduction to structural equation modeling using IBM SPSS statistics and AMOS. Los Angeles: Sage; 2012.

43. Saffi MA, Jacques de Macedo Junior LJ, Trojahn MM, Polanczyk CA, Rabelo-Silva ER. Validity and reliability of a questionnaire on knowledge of cardiovascular risk factors for use in Brazil. Rev Esc Enferm USP. 2013;47(5):1084-90.

44. Nascimento Junior JRA, Vieira LF, Rosado AFB, Serpa S. Validação do Questionário de Ambiente de Grupo (GEQ) para a língua portuguesa Validation of the Group Environment Questionnaire (GEQ) for Portuguese language. Motriz: J. Phys. Ed. 2012;18(4):770-82.

45. Guedes DP, Legnani RFS, Legnani E. Propriedades psicométricas da versão brasileira do Exercise Motivations Inventory (EMI-2). Motriz: J. Phys. Ed. 2012;18(4):667-77.

46. Núñez JL, Martín-Albo J, Navarro JG, González VM. Preliminary validation of a Spanish version of the Sport Motivation Scale. Percept Mot Skills. 2006;102(3):919-30.

47. Raimundi MJ, Reigal RE, Hernández Mendo A. Adaptación argentina del Inventario Psicológico de Ejecución Deportiva (IPED): validez, fiabilidad y precisión. CUADERNOS DE PSICOLOGÍA DEL DEPORT. 2016;16(1):211-22.

48. Gómez-Carmona P, Cervera V, Benito P. Diseño y validación de un cuestionario socio-emocional para jóvenes futbolistas de élite/Design and validation of a socio-emotional questionnaire for youth football players. Rev. int. med. cienc. act. fís. deporte. 2016(55).

49. Marchal-Bertrand L, Espada JP, Morales A, Gómez-Lugo M, Soler F, Vallejo-Medina P. Adaptation, validation and reliability of the Massachusetts General Hospital-Sexual Functioning Questionnaire in a Colombian sample and factorial equivalence with the Spanish version. Rev Latinoam Psicol. 2016;48(2):88-97.

50. Brown TA. Confirmatory factor analysis for applied research. New York: Guilford Publications; 2014.

51. Hair J, Anderson R, Tatham R, Black W. Análise multivariada de dados. Trad. Adonai S. Sant'Anna e Anselmo C. Neto. Porto Alegre: Bookman; 2005.

52. Feu S. Estudio de los modelos y variables que afectan al entrenador español de balonmano [Tesis doctoral]. Caceres: Universidad de Extremadura; 2004.

53. Balbinotti MAA. Para se avaliar o que se espera: reflexões acerca da validade dos testes psicológicos. Aletheia. 2005;21:43-52.

54. Hagger M, Ashford B, Stambulova N. Physical self-perceptions: A cross-cultural assessment in Russian children. European Journal of Physical Education. 1997;2(2):228-45.

55. Magallares A, Graffigna G, Barello S, Bonanomi A, Lozza E. Spanish adaptation of the Patient Health Engagement scale (S.PHE-s)in patients with chronic diseases. Psicothema. 2017;29(3):408-13.

56. Nascimento Junior JRAd, Vissoci JRN, Lavallee D, Vieira LF. Adaptation and validation of the Sport Multidimensional Perfectionism Scale-2 (SMPS-2) for the Brazilian sport context. Motriz: J. Phys. Ed. 2015;21(2):125-36. 
57. Callegaro Borsa J, Figueredo Damásio B, Ruschel Bandeira D. Adaptação e validação de instrumentos psicológicos entre culturas: algumas considerações. Paidéia. 2012;22(53):423 - 32.

58. Vergara AI, Balluerka N. Metodología en la investigación transcultural: perspectivas actuales. Psicothema. 2000;12(Suplemento):557-62.

\section{Corresponding author}

Jose Carlos Mendes

UNIOESTE - CCHEL

Rua Pernambuco, 1777 - Marechal Cândido Rondon - Paraná 85960-000, Brazil

Email: jose.mendes@unioeste.br

Manuscript received on May 24, 2019

Manuscript accepted on June 18, 2019

(c) ()

Motriz. The Journal of Physical Education. UNESP. Rio Claro, SP, Brazil - eISSN: 1980-6574 - under a license Creative Commons - Version 4.0 